\title{
Ladder drill portable: Agility tools for sports
}

\author{
Ni Putu Nita Wijayanti* ${ }^{*}$, Deny Pradana Saputro ${ }^{\circledR}$, \\ Oca Fernandes AF ${ }^{\mathbb{D}}$, Raja Febri
}

\author{
Universitas Riau, Indonesia \\ Received: 26 November 2020; Accepted 06 February 2021; Published 25 March 2021 \\ Ed 2021; 6(1): 98-108
}

\begin{abstract}
The development of portable ladder drills as a medium for agility training has never been touched once. The ladder drill tool's mobile concept will make it easier for the trainer to use the device with a variety of varied agility training movements and can be used in more sports. Based on this, the research is carried out in an effort to make portable ladder drill training media that is useful as a medium for agility training. This research uses research and development level 3 methods. Product trials are conducted in three types, that is one on one practices with four respondents, small group trials worked with five respondents athletes, students majoring in Sports Education FKIP Universitas Riau, and large-scale tests. They work on 11 athletes KONI and Dispora Riau Province. The data analysis technique used in this research is the quantitative descriptive analysis technique. Furthermore, data collection techniques use a questionnaire (questionnaire). The results of this study indicate that: assessments made by material experts, media experts, one-on-one trials, small-scale trials, and large-scale trials are above 83 percent. Based on this study results, it can be concluded that the development of portable ladder drills is declared feasible as a medium to increase agility by sports actors. Considering that this development still has shortcomings, future research recommendations are related to providing cheaper and more functional product materials in terms of equipment installation efficiency.
\end{abstract}

Keywords: Ladder drill portable; agility; media; excercise

https://doi.org/10.25299/sportarea.2021.vol6(1).5912

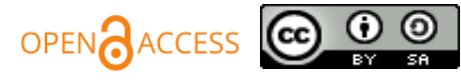

Copyright @ 2021 Ni Putu Nita Wijayanti, Deny Pradana Saputro, Oca Fernandes AF, Raja Febri

Corresponding author: Ni Putu Nita Wijayanti, Physical Education Health and Recreation, Universitas Riau, Pekanbaru, Riau, Indonesia

Email: nitawijayanti987@gmail.com

How To Cite: Wijayanti, N. P. N., Saputro, D. P., AF, O. F., Febri, R. (2020). Ladder drill portable: Agility tools for sports. Journal Sport Area, 6(1), 98-108. https://doi.org/10.25299/sportarea.2021.vol6(1).5912

\section{INTRODUCTION}

Coaching is an absolute thing in order to achieve maximum performance in sports. This statement is in accordance with what was conveyed by Harsono (2017) that coaching or training for athletes has the aim of the process of increasing skills and maximum achievement. The improvement process carried out includes increasing the physical, mental, technical, and tactical dimensions.

Judging from the mental aspect, a coach must try to help athletes believe in the abilities they have during and before the match, because this self-efficacy will have a positive impact on self-confidence and performance during the match (Mamassis \& Doganis, 2004). Furthermore, with regard to technique and tactics, this requires that the development of strategy is not only to outwit opponents, but also applies during training and competition to make it more efficient (Durand-Bush \& Salmela, 2002). These dimensions are very important and guidance needs to be carried out through systematic and continuous training. From several dimensions that need to be developed, Bompa and Haff (2009) state that the physical component is 
the main dimension that needs to be developed. This is because a strong physical foundation has good potential to develop the technical, tactical, and psychological / mental dimensions.

The physical component itself is a dimension related to the biomotor component. Sukadiyanto and Muluk (2011) defines biomotor as the ability to move each individual who is influenced by the condition of the internal organ systems. These internal organ systems include the respiratory, neuromuscular, circulatory, digestive, bone, and joint energy systems. Bompa and Buzzichelli (2015) in his book describes a close relationship between each biomotor component. It can be said that in general the biomotor component is divided into two parts, namely the main biomotor component, and the biomotor component formed from the main biomotor component. Some of the main biomotor components include strength, endurance, speed, coordination, and flexibility. While biomotor components such as muscle endurance, speed endurance, agility, power, and several other components are components of the formation of the main biomotor components (Bompa \& Buzzichelli, 2015).

Of the several existing biomotor components, agility is an important aspect to be improved, especially in sports that require high agility such as badminton, football, Pencak Silat, and several other sports. This can be seen from some of the efforts of coaches and researchers about agility in certain sports such as those carried out by Yuliawan and Sugiyanto (2014), next by Ahmad (2018), and Samsudin and Furkan (2017). Based on the exposure of several previous studies, it can be concluded that agility is very important to be developed. Other research by Dewi and Vanagosi (2018) also shows that agility is something very important. The study attempted to examine the effect of running a "W" running exercise on an increase in the agility component. In addition, given the importance of agility in order to achieve achievements in certain sports, efforts have also been made to procure tools used as a medium for agility training. This can be seen from research from (Nugraha, 2015). The research produced a tool that can be used to train agility in badminton. Based on the researcher's analysis, this tool is only used in one sport and of course it is less portable for other sports. Other research was also carried out by Aji (2016) who tries to create a training medium in the form of a ladder as an effort to increase power, agility, and coordination. Looking at the specifications of the tool, again the ladder drill product being developed is not portable. The tool cannot be assembled and assembled according to the form of agility training expected by the trainer.

However, if the researcher looks further at the articles in several previous studies, the tool that is created is only used in one straight direction of motion, it cannot be varied with the needs of the sport. This makes the tools that have been created very limited in use in certain agility movements and limited sports. Seeing these limitations, the researchers then attempted to create a tool that is almost portable for all agility training movements that are modified to suit the needs of sports that require agility biomotor components. This tool will be called a portable ladder drill. Portable here means that it can be used in several kinds of sports that have the need for agility biomotor components, are easy to use and can be assembled according to the needs of the sport.

Given the importance of this agility training, the procurement of this portable ladder drill media is very important. The equipment that will be created offers a multi-functional use (All in One). In addition, the tools used are also easy to obtain and do not require expensive costs. This procurement effort is expected to make it easier for trainers to easily create a variety of exercises and procure equipment that supports agility training.

\section{METHODS}

The method used in this research is the level 3 research and development method. The level 3 research and development method according to Sugiyono (2019) is a scientific method used to research and test existing products. The stages of research and development for level 3 version Sugiyono (2019) can be seen in the figure 1: 


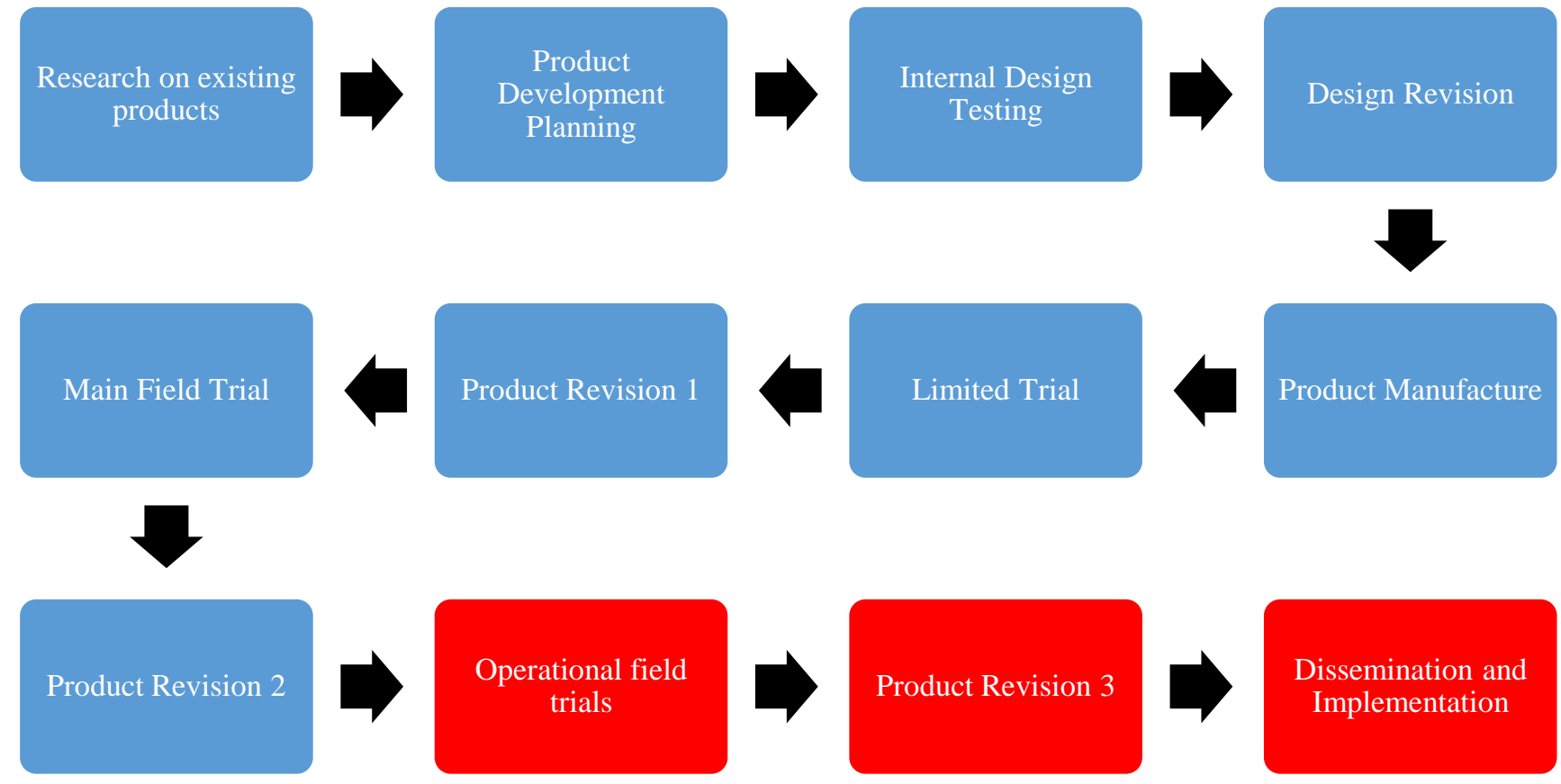

Figure 1. Stages of Research and Development Level 3

(Sugiyono, 2019)

In the first stage, research on existing products is an activity to analyze several previous studies by mapping the articles that the author has done. Several studies that resulted in ladder drill products then the authors analyze some of its shortcomings to get a research gap (gap of research) that the author can enter. After the research gap is obtained, then in the second stage, the authors begin to plan product development. Product development planning is the result of analyzing several existing products in the first stage by producing an initial product design. The initial design of this product will be continued in the third step, namely internal design testing. This internal design test includes validation of several experts (Media and Material Experts) and 1 vs 1 product testing. If at this stage there are several revisions, then the next step is design revision. This fourth step can be skipped to the next step if there is no revision. If there is, it is necessary to revise the design according to the input of experts and practitioners. Next, enter the fifth step, namely product manufacturing. The manufacture of this product is carried out based on input from experts and at the same time based on the map results in the previous step. Maping activities and expert input on the internal design test are then outlined in the form of a product which will later be tested in the sixth step, which is a limited trial. In the limited trial phase, researchers involve 5 subjects to test the products they make. After the testing process through the use of the product has been carried out, the author asks for feedback in the form of criticism and suggestions through the assessment form that has been distributed. If there is a revision in this phase, then continue to the seventh step, namely product revision 1. If there is no revision, you can proceed to the next stage, namely the main field trial stage. In the main field trial, the researcher experiences difficulties in collecting testee. Supposedly, the test subjects in the main field trials need to involve a lot of people. Since the research is still in a state of the Covid-19 pandemic, it is not possible to collect more subjects. In the main field trial stage (step eight) the researcher is only able to collect as many as 11 subjects (not meeting the requirements, namely around 30-100 subjects). This is also a weakness in this study. At this stage, if there is still a revision, the ninth step will be continued, namely product revision 2. It should be underlined that in this research and development stage, the research and development stage only reach the ninth stage, namely product revision 2 . This is due to the grant funds used insufficient. If possible, it will be followed up on a new grant proposal the following year.

Furthermore, with regard to the data, this study obtains research data from the results of expert validation involving 1 material expert and 1 media expert. Then the trial is continued in the $1 \mathrm{vs} 1$ product test, limited 
trial and main field. In the 1 vs 1 trial involving 4 subjects, the limited trial involves 5 subjects while the main field trial involves 11 subjects.

The data collected in this study use a questionnaire. According to Sugiyono (2019) questionnaire is one of the data collection techniques by giving questions or statements to respondents to be answered. The questionnaire used contains several statements made by the researcher based on the field needs analysis. Furthermore, the questionnaire that is made is submitted to material experts, media, and users to be given an assessment along with input on the product being developed. The questionnaire submitted to material experts includes 3 assessment dimensions, namely: ladder drill product design with 4 assessment indicators, product innovation with 4 assessment indicators, and benefits with 3 assessment indicators. Furthermore, the questionnaire submitted to media experts has three dimensions: product display with 3 assessment indicators, product innovation with 4 assessment indicators and materials with 2 assessment indicators. Furthermore, the questionnaire given to users includes several dimensions of assessment. Among them are: product display dimensions with 3 assessment indicators, product innovation dimensions with 4 assessment indicators, and product function dimensions with 3 assessment indicators.

Furthermore, the data analysis technique used in this research is the descriptive quantitative data analysis technique. The use of descriptive data analysis techniques describes the results of the validation of media and material experts. Furthermore, to describe the assessment tool developed in the 1 vs 1 test involves 4 subjects, 5 subjects on a small scale, and 11 subjects on a large scale. Quantitatively, this technique is used to see the percentage of the assessment made by the respondent. Percentage calculation according to (Sudjono, 2009), $\mathrm{p}=\mathrm{f} / \mathrm{N} \times 100 \%$ with $\mathrm{f}=$ the frequency for which the percentage is being sought; $\mathrm{N}=$ Number of cases; and $\mathrm{p}=$ percentage figures.

\section{RESULTS AND DISCUSSIONS}

\section{Product Description "Ladder Drill Portable"}

The development of portable ladder drill products is developed to provide innovation and effectiveness in training agility physical condition components. The ladder drills that are generally used by trainers and athletes in Indonesia are generally one-way, so they are very limited in carrying out variations. The advantage of this product compared to ladder drills in general is that the blades can be removed and installed according to the training needs of the sport, so that it is more multi-functional, besides the variety of movements that are designed is unlimited. The "Portable Ladder Drill" product is developed using materials such as: webbing (flat rope / pipe), magnets, for ladder blades made of composite polymer materials, rubber, needles, and threads.

\section{Results of Product Development "Portable Ladder Drill"}

\section{Assessement of Expert}

a) Expert Assessment of Material Step I

The product validator developed in this study is Agus Sulastio, M.Pd, who is a lecturer in the Sports Coaching Education Study Program, Faculty of Teacher Training and Education, Universitas Riau. His selection as a material expert is due to his ability in the field of sports achievements, talent identification, physical tests, and capable of teaching physical improvement courses which are quite capable and can be proven in several studies that he has done in several accredited national journals. Furthermore, related to the data on the results of portable ladder drill from the assessor of the first stage material dimensions in more detail in table 1.

Table 1. Results of the Assessment of Material Experts I

\begin{tabular}{clcccc}
\hline No & Dimension & Score Earnings & Top Score & Percentage (\%) & Category \\
\hline 1 & Product Design & 15 & 20 & $75 \%$ & Decent Enough \\
2 & Product Innovation & 15 & 20 & $75 \%$ & Decent Enough \\
3 & Product Benefits & 11 & 15 & $73 \%$ & Decent Enough \\
\hline & Total Scores & $\mathbf{4 1}$ & $\mathbf{5 5}$ & $\mathbf{7 4 . 5 \%}$ & Decent Enough \\
\hline
\end{tabular}


Table 1, when it is viewed from all dimensions, namely the dimensions of design, innovation and product benefits, it shows that the material expert at stage I gives a fairly decent assessment. Phase I will later be continued in stage two to provide the revised product results to material experts.

b) Media Member Evaluation Data Level I

I.B Gede Dharma Saputra, S.T in this study is involved as a media assessor / validator. He has expertise in materials engineering - metallurgy. He has competence in the fields required in the development of this product. He is able to provide an assessment and input on products, for example the selection of the right ingredients, as well as efficient product manufacturing techniques. Further results of expert judgment can be seen in table 2.

Table 2. Validation Results of Phase I Media Experts

\begin{tabular}{clcccc}
\hline No & Dimension & Score Earning & Top Score & Percentage (\%) & Category \\
\hline 1 & Product Display & 11 & 15 & s73.3\% & Decent Enough \\
2 & Product Innovation & 13 & 20 & $65 \%$ & Decent Enough \\
3 & Material & 7 & 10 & $70 \%$ & Decent Enough \\
4 & Application & 7 & 10 & $70 \%$ & Decent Enough \\
\hline \multicolumn{2}{r}{ Total Scores } & $\mathbf{3 8}$ & $\mathbf{5 5}$ & $\mathbf{6 9 . 0 9 \%}$ & Decent Enough \\
\hline
\end{tabular}

Table 2 is results of the stage I media expert's assessment when it is viewed from all dimensions, namely the dimensions of appearance, innovation, materials and applications, it shows that the media expert at stage I gave a fairly decent assessment. Phase I will be continued in stage two to provide the revised product results to media experts.

c) Level II Material Expert Assessment Data

Table 3. Material Expert Assessment Phase II

\begin{tabular}{clcccc}
\hline No & \multicolumn{1}{c}{ Dimension } & Score Earning & Top Score & Percentage (\%) & Category \\
\hline 1 & Product Design & 17 & 20 & $85 \%$ & Decent \\
2 & Product Innovation & 18 & 20 & $90 \%$ & Decent \\
3 & Product Benefits & 12 & 15 & $80 \%$ & Decent \\
\hline \multicolumn{2}{r}{ Total Scores } & $\mathbf{4 7}$ & $\mathbf{5 5}$ & $\mathbf{8 5 . 4 5 \%}$ & Decent \\
\hline
\end{tabular}

Table 3, when it is viewed from all dimensions, namely the dimensions of design, innovation, and product benefits, it shows that the material expert in stage II gives a proper assessment. The next step is to try it at an advanced stage, namely the 1 vs 1 trial stage, small scale, and large scale.

d) Media Expert Rating Data II

Table 4. Results of Media Expert Assessment Phase II

\begin{tabular}{clcccc}
\hline No & \multicolumn{1}{c}{ Dimension } & Score Earning & Top Score & Percentage (\%) & Category \\
\hline 1 & Product Display & 13 & 15 & $86.67 \%$ & Decent \\
2 & Product Innovation & 17 & 20 & $85 \%$ & Decent \\
3 & material & 8 & 10 & $80 \%$ & Decent \\
4 & Application & 8 & 10 & $80 \%$ & Decent \\
\hline \multicolumn{2}{r}{ Total Scores } & $\mathbf{4 6}$ & $\mathbf{5 5}$ & $\mathbf{8 3 . 6 \%}$ & Decent \\
\hline
\end{tabular}

Table 4, when it is viewed from all dimensions, namely dimensions of product display, product innovation, materials, and applications, it shows that the media expert in stage II gave a proper assessment. The next step is to try it at the 1 on 1 trial stage, on a small and large scale. 


\section{Product Revision I}

a) Initial Product

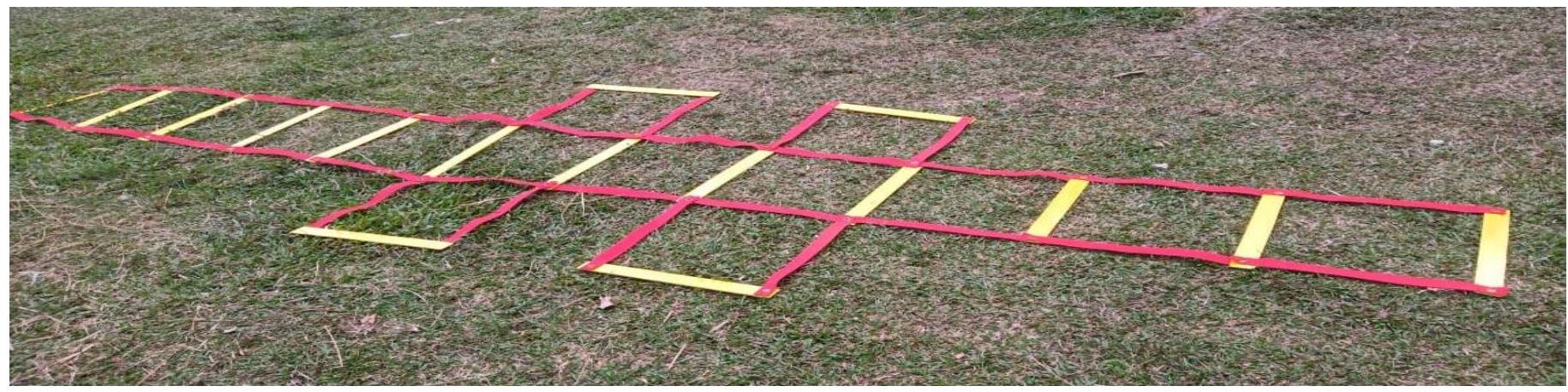

Figure 2. Product "Ladder Drill Portable" before Revision (Personal Doc.)

Product Descriptions:

1) The length of the blade is $50 \mathrm{~cm}$ and the width is $5 \mathrm{~cm}$.

2) The length of the webbing is $50 \mathrm{~cm}$ and the width is $3.5 \mathrm{~cm}$.

3) There are 60 magnets with the size of $3 \times 0.5 \mathrm{~cm}$.

\section{b) Product Revision Results}

Product revision activities can be carried out after the "portable ladder drill" product has received value, input, and suggestions for appropriate improvements. Related to the advice from the material expert, namely that the blade is made smaller and the junction between the blade and the webbing band is added with one magnet each, this is done in order to provide more flexibility for the athlete. The media expert gives advice that the magnets in the initial design of the product are implanted and cast on the revised composite polymer, only implanted, not cast again, replacing magnets so that the webbing blades and tape can be firmly adhered, and the base of the blades is added with rubber to reduce the likelihood of the athlete slipping when practice.

Furthermore, for suggestions from media and material experts, the researchers improve several things. The researcher replaces the ladder blades to be smaller than the previous one, each junction of the blade and the webbing tape is added with a magnet, the magnet is replaced with a stronger magnet and it is only planted on the blade, then the base of the blade is given a kind of rubber so that the base of the blade s not slippery.

The stages of developing the "portable ladder drill" are validated by the expert twice. While the product revision is 1 time. The next step after some input from the experts is corrected, the researcher conducts trials on athletes assisted by KONI and Dispora in Riau Province who are studying at the Sports Education Campus of FKIP, Universitas Riau.

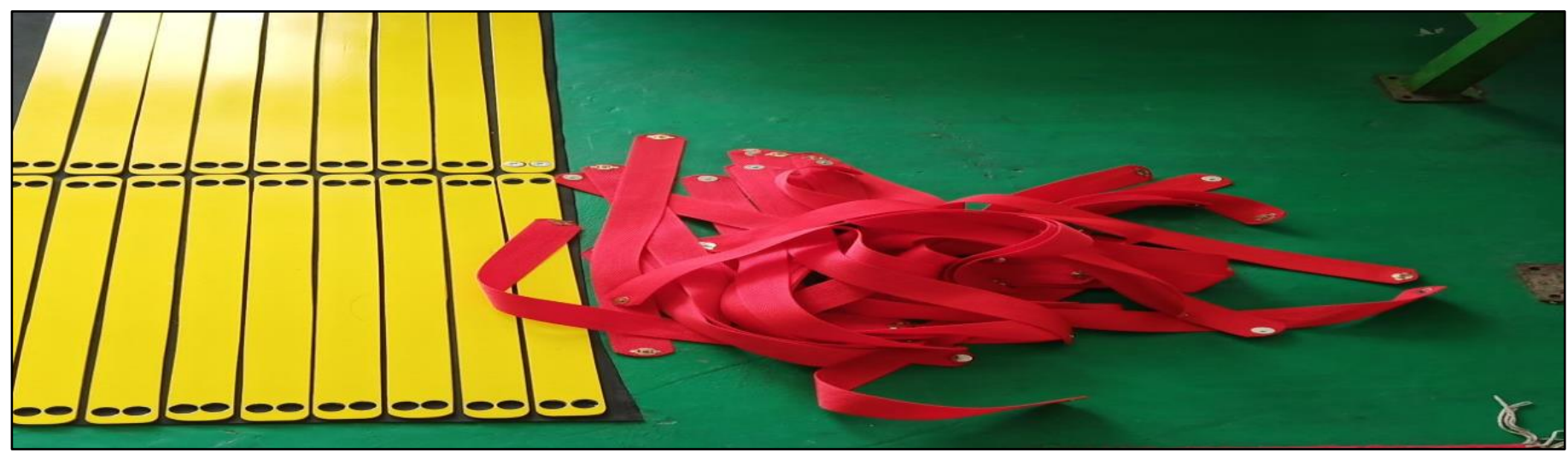

Figure 3. Product “Ladder Drill Portable” after Revision (Personal Doc.) 
Product Descriptions:

1) The length of the blade is $50 \mathrm{~cm}$ and the width is $3.5 \mathrm{~cm}$.

2) The length of the webbing is $52 \mathrm{~cm}$ and the width is $3.5 \mathrm{~cm}$.

3) There are 96 magnets with the size of $3 \times 0.5 \mathrm{~cm}$.

4) The blade base rubber material is sponge rubber.

\section{Product Trial}

a) 1 on 1 Trial

This stage is carried out on student respondents from the Department of Sports Education, FKIP Universitas Riau. The mechanism for implementing the 1 vs 1 trial can be explained in several stages: (1) At the time of the explanation of the "portable ladder drill" the respondent looks happy, enthusiastic, curious, and many questions are submitted to the researcher. (2) Respondents also look enthusiastic and excited. Some respondents ask the researcher what ladder designs can be formed with portable blades. The number of samples involved is 4 people.

Table 5. Results of 1 vs 1 Trial Assessment

\begin{tabular}{|c|c|c|c|c|c|}
\hline No & Dimension & Score Earning & Top Score & Percentage (\%) & Category \\
\hline 1 & Product Display & 50 & 60 & $83.33 \%$ & Decent \\
\hline 2 & Product Innovation & 68 & 80 & $85 \%$ & Decent \\
\hline 3 & Product Functions & 50 & 60 & $83.33 \%$ & Decent \\
\hline & Total Scores & 168 & 200 & $84 \%$ & Decent \\
\hline
\end{tabular}

The results of the assessment are based on table 5 regarding "portable ladder drill" of $83.33 \%$ of the display dimensions with the "feasible" category. Furthermore, from the point of view of product innovation, it receives an assessment of $85 \%$ which is included in the "feasible" category, while the assessment of the product function dimension receives an assessment of $83.33 \%$ which is also included in the "feasible" category with a total overall assessment of $84 \%$.

\section{b) Limited Trial}

The activity in this test involves 5 subjects. As for the details of these activities: (1) when the researcher explains the product, the test subjects look enthusiastic and curious and many questions arise about the mechanism of using the "portable ladder drill", (2) the activity begins with prayer and warm-up then the research subjects carried out the exercise movement agility, (3) at the end of the activity, cooling is carried out followed by filling out a questionnaire. The data on the results of a small group trial questionnaire for Student Athletes of the Department of Sports Education, FKIP, Universitas Riau can be seen in table 6.

Table 6. Limited Trial Questionnaire Results

\begin{tabular}{clcccc}
\hline No & Dimension & Score Earning & Top Score & Percentage (\%) & Category \\
\hline 1 & Product Display & 64 & 75 & $85.33 \%$ & Decent \\
2 & Product Innovation & 87 & 100 & $87 \%$ & Decent \\
3 & Product Functions & 63 & 75 & $84 \%$ & Decent \\
\hline \multicolumn{2}{r}{ Total Scores } & $\mathbf{2 1 4}$ & $\mathbf{2 5 0}$ & $\mathbf{8 5 . 6 0 \%}$ & Decent \\
\hline
\end{tabular}

The results of the questionnaire show that in the assessment of product appearance of $85.33 \%$ or "feasible", the product innovation dimension was $87 \%$ or "feasible", while the assessment of the product function dimension receives an assessment of $84 \%$ which also fell into the "feasible" category. The total assessment of the feasibility test for research "ladder drill portable" according to respondents is $85.60 \%$ categorized as "feasible".

c) Main Field Trial

The trial at this stage is carried out on 11 respondents or athletes of KONI and Dispora in Riau Province. These activities are detailed: (1) when the researcher explained the product, the test subjects look 
enthusiastic and curious and many questions arise about the mechanism of using the "portable ladder drill", (2) the activity begins with prayer and warm-up, then the research subjects carry out agility exercise movements, (3) at the end of the activity, a cool down is carried out, after which the assessment is carried out by means of a questionnaire. The questionnaire results can be seen in table 7 .

Table 7. Results of the Main Field Trial Questionnaire

\begin{tabular}{cccccc}
\hline No & Dimension & Score Earning & Top Score & Percentage (\%) & Category \\
\hline 1 & Product Display & 135 & 155 & $87.09 \%$ & Decent \\
2 & Product Innovation & 197 & 220 & $89.54 \%$ & Decent \\
3 & Product Functions & 134 & 155 & $86.45 \%$ & Decent \\
\hline & Total Scores & $\mathbf{4 6 6}$ & $\mathbf{5 3 0}$ & $\mathbf{8 7 . 9 2 \%}$ & Decent \\
\hline
\end{tabular}

Table 7 shows that the assessment on the product display is $87.09 \%$ or "feasible", the product innovation dimension is $89.54 \%$ or "feasible", while the assessment of the function dimension of $86.45 \%$ is also in the "feasible" category. Furthermore, in relation to the number of feasibility test assessments for research "ladder drill portable" according to respondents, $87.92 \%$ is categorized as "feasible".

With regards to the agility ladder, this tool can not only be used for speed training media from the feet, if it is used in various forms, the agility ladder can be a multi-use tool (Efendi \& Sandra, 2019). This is in accordance with the findings in the results of this study that the development of the "portable ladder drill" is made into a media product to assist agility training and can even be used for coordination training for athletes from various sports. The development process is carried out through research and development procedures, starting from the planning stage (training media development), the media creation process and evaluation instruments. In the first stage of validation, the material expert obtains a percentage of $74.5 \%$, with the category "quite feasible". After getting input from experts, the researcher then revises it and carriy out the second stage of validation with a percentage of $84.45 \%$, with the category being "feasible". In addition, based on the first stage of expert validation, the percentage is $69.09 \%$ with the category "quite feasible". Furthermore, in the second stage, it gets $83.6 \%$, with the category "feasible".

After the product is tested for validation through material and media experts, the portable ladder drill is categorized as Eligible for testing. Trials have been carried out through 1 on 1 trials, Limited and large trials. For the 1 vs 1 trial with 4 subjects, it is found that $84 \%$ of the research feasibility test is "portable ladder drill", which means that the training aid is "feasible" to be tested. For small group trials, according to the respondents, the assessment of the feasibility test of "portable ladder drill" is $85.60 \%$, which means that the tool is "feasible" to be tested on a large scale. Finally, for the Main Field Trial of 11 respondents, it is found that the feasibility test of the "portable ladder drill" research according to the respondents was $87.92 \%$ which means that the training aids are categorized as "feasible". The ladder drill tool is a very important tool in order to improve the biomotor component, especially the agility biomotor component. This is in line with what there are. There are many studies that discuss ladder drill tools to increase certain biomotor components, such as in research studies Pradana, Farhanto, \& Setiawan (2018) which can develop variations of ladder drill exercises for elementary school students and get products that are feasible to use. In addition, the use of a ladder drill as a training aid has been shown to increase the biomotor component of agility, as in research Hadi, Fahrial, and Amiq (2016) about the success of improving the agility of U-17 football students using ladder exercises. Still around the football game, in other research by Robin and Raj (2019) with a sample of 30 soccer player students from Sree Sankaracharya University of Sanskrit, it is also found that the research results show that the ladder drill is a feasible method to improve agility performance. In fact, ladder drill exercises are on research Nuryadi and Firmansyah (2018) also increase the running speed of 60 meters at the basketball target schools. This ladder drill also has the effect of increasing agility performance on 48 semi-professional female Kabaddi players in schools and colleges (Pawar \& Borkar, 2018). This research is also consistent with the findings Ravi and Kalimuthu (2019) that with the ladder drill program for 6 weeks is able to provide a significant increase in speed. Almost similar to the findings Kusnanik and Rattray (2017) that there is a significant effect of ladder running speed and repetitive sprinting ability in increasing agility and speed. Not only that, training using a ladder drill can also increase the explosive power of the leg 
muscles and speed (Pelamonia \& Harmono, 2018). Some of the research results are in accordance with what was stated Schreiner (2003) that the ladder drill is an important tool for conditioning speed, agility and coordination.

Seeing the many studies uses ladder drills that have reaped many successes, it further strengthens that the development of this tool is not in vain considering that the tool created is also portable for several exercises and can be used in many sports that require agility. If we look further, this developes tool has several advantages as well as several drawbacks. There are several advantages and disadvantages, including: (a) provide media solutions or agility training aids to coaches and athletes more effectively and efficiently in accordance with the characteristics of the sport, (b) provide opportunities for coaches and athletes to develop imagination and creativity in making various training patterns, (c) easy to operate as all blades can be attached freely. While the drawbacks are: (a) the production process of the tool is very costly because the quality of the "Ladder Drill Portable" material is much better, (b) requires more installation time than the ladder in general. If we look further about the implications of the Multifunctional Portable Ladder Drill as an Agility Training Aid it has practical benefits that can be used to design agility training according to sports, optimizing the creativity of coaches and athletes in creating agility training patterns, the basis for making better advanced training media longer for researchers, and has opportunities as a tool with which to make athletes work out the maximum.

\section{CONCLUSION}

The results of the research "the development of a multifunctional portable ladder drill media as a tool for agility training" are declared feasible to be used as a training tool to explain agility. Even considering that the developed tool is portable, it is also possible to use it as a medium for coordination and reaction training. The results of this research and development have weaknesses. This weakness lies in the limited number of research subjects due to following health protocols during the Covid-19 Pandemic, making prototypes and Portable Ladder Drill products takes a long time because the materials and tools used are difficult to find and need a special process, and the process of making Ladder Drill. Portable author does not include in detail. Given that this development still has shortcomings, the recommendation for further research is to try out the developed product on a larger subject. Recommendations for future research are related to the provision of cheaper and more practical product materials so that the product can be used by all groups.

\section{REFERENCES}

Ahmad, N. (2018). Pengaruh Latihan Zig Zag Run Terhadap Kelincahan Atlet Pencak Silat Tapak Suci Lebong. Journal Physical Education, Health and Recreation, 2(2), 181-185. https://doi.org/10.24114/pjkr.v2i2.9589

Aji, G. P. (2016). Pengembangan Alat Ladder Untuk Latihan Koordinasi, Kelincahan dan Power. Skripsi, Program Studi Pendidikan Kepelatihan Olahraga, Jurusan Pendidikan Kepelatihan, Fakultas Ilmu Keolahrgaan, Universitas Negeri Yogyakarta.

Bompa, T., \& Buzzichelli, C. (2015). Periodization Training for Sports-3rd Edition. Champaign, IL, USA: Human Kinetics.

Bompa, T. O., \& Haff, G. G. (2009). Periodization: Theory and methodology of training.[5-th Edition]. Champaign, IL, USA: Human Kinetics.

Dewi, P. C., \& Vanagosi, K. D. (2018). Pelatihan Lari Huruf W dan Kelincahan. Jurnal Pendidikan Kesehatan Rekreasi, 4(2), 68-73. 
Durand-Bush, N., \& Salmela, J. H. (2002). The development and maintenance of expert athletic performance: Perceptions of world and olympic champions. Journal of Applied Sport Psychology, 14(3), 154-171. https://doi.org/10.1080/10413200290103473

Efendi, D. I., \& Sandra, I. A. (2019). Pengaruh Latihan Ladder Drill Terhadap Kelincahan Pada Anak Usia Dini Kelompok B di Taman Kanak-Kanak. Seminar Nasional Penelitian dan Pengabdian Masyarakat, $16-21$.

Hadi, F. S., Fahrial, E. H., \& Amiq, F. (2016). Pengaruh Latihan Ladder Drills Terhadap Peningkatan Kelincahan Siswa U-17 di Persatuan Sepakbola Jajag Kabupaten Banyuwangi. Jurnal Pendidikan Jasmani, 26(1), 213-228. http://dx.doi.org/10.17977/pj.v26i1.7748.g3566

Harsono. (2017). Kepelatihan olahraga. Teori dan metodologi. Bandung: PT. Remaja Rosdakarya.

Kusnanik, N. W., \& Rattray, B. (2017). Effect of Ladder Speed Run and Repeated Sprint Ability in Improving. Acta Kinesiologica, 11(1), 19-22.

Robin, K. V, \& Raj, Y. C. L. (2019). Impact of ladder training on the agility performance of footballers. International Journal of Yogic, Human Movement and Sports Sciences, 4(1)(1), 779-781.

Mamassis, G., \& Doganis, G. (2004). The effects of a mental training program on juniors pre-competitive anxiety, self-confidence, and tennis performance. Journal of Applied Sport Psychology, 16(2), 118137. https://doi.org/10.1080/10413200490437903

Nugraha, F. (2015). Pengembangan Sinyal Lampu 3 Warna Untuk Alat Bantu Kelincahan Footwork Pada Klub Pb . Mandiri Pati Tahun 2015. Thesis. Universitas Negeri Semarang.

Nuryadi, A., \& Firmansyah, G. (2018). Pengaruh Latihan Ladder Drill Terhadap Kecepatan Lari 60 Meter Pada Siswa Sekolah Bola Basket Loc Sidoarjo. JP.JOK (Jurnal Pendidikan Jasmani, Olahraga dan Kesehatan), 2(1), 63-69. https://doi.org/10.33503/jpjok.v2i1.191

Pawar, S. B., \& Borkar, P. (2018). Effect of ladder drills training in female kabaddi players. International Journal of Physical Education, Sports and Health, 5(2), 180-184.

Pelamonia, S. P., \& Harmono, B. A. (2018). Pengaruh Pelatihan Ladder Drill 90 Degree Rotation dan Ladder Drill Ali Shuffle Terhadap Peningkatan Daya Ledak Otot Tungkai dan Kecepatan. JP.JOK (Jurnal Pendidikan Jasmani, Olahraga dan Kesehatan), 2(1), 20-29. https://doi.org/10.33503/jpjok.v2i1.181

Pradana, J. S., Farhanto, G., \& Setiawan, W. (2018). Pengembangan Variasi Latihan Ladder Drill Pada Peserta Ekstrakurikuler Sepakbola Semester Ganjil SDN 1 Cluring Tahun Ajaran 2018/2019. Jurnal Kejaora (Kesehatan Jasmani dan Olahraga), 3(2), 209-217. https://doi.org/10.36526/kejaora.v3i2.215

Ravi, P., \& Kalimuthu, D. (2019). The effects of ladder training on speed of Egyptian high school boys student's in Qatar. International Journal of Physical Education, Sports and Health, 6(1), 19-22.

Samsudin., \& Furkan. (2017). Pengaruh latihan kelincahan terhadap keterampilan menggiring bola dalam permainan sepak bola. Jurnal Pendidikan Olahraga, 7(1), 1-7.

Schreiner, P. (2003). Effective use of the agility ladder for soccer. Aiburn, Michigan: Reedswain Publishing. 
Sudjono, A. (2009). Pengantar Evaluasi Pendidikan. Jakarta: PT Raja Grafindo Persada.

Sugiyono. (2019). Metode Penelitian Pendidikan (Kuantitatif, Kualitatif, Kombinasi, R\&D, dan Penelitian Pendidikan). Bandung: ALFABETA.

Sukadiyanto., \& Muluk, D. (2011). Pengantar teori dan metodologi melatih fisik. Bandung: CV. Lubuk Agung.

Yuliawan, D., \& Sugiyanto, F. (2014). Pengaruh Metode Latihan Pukulan dan Kelincahan Terhadap Keterampilan Bermain Bulutangkis Atlet Tingkat Pemula. Jurnal Keolahragaan, 2(2), 145-154. https://doi.org/10.21831/jk.v2i2.2610 